\title{
ADMISSIONS IMPLIED FROM SPOLIATION OR RELATED CONDUCT ${ }^{1}$
}

\author{
JOHN MacARTHUR MAGUIRE* and ROBERT C. VINCENT $†$
}

I

\section{Introductory Analysis}

$T^{\mathrm{HE}}$ extreme importance of admissions and confessions in trial work 1 needs no emphasis. Every lawyer knows it, and every volume of reports bespeaks it. But the present discussion demands a careful classification of admissions, and we must therefore define our topic. If a defendant says: "I owe the plaintiff one hundred dollars," we have an express admission of what may be called the direct type. If the same defendant's duly authorized agent ${ }^{2}$ says to plaintiff: "My principal owes you one hundred dollars," we again have an express admission, but this time of the vicarious type. If plaintiff says to defendant: "You owe me one hundred dollars," and defendant says "Yes" or nods his head, our admission is still express, but now adoptive in form. ${ }^{3}$ We probably get into the realm of implied admissions with evidence that the defendant, charged by plaintiff with owing the latter one hundred dollars, simply stood mute. We certainly get there with evidence that defendant tore out of his books and burned the pages showing the state of his account with plaintiff. ${ }^{4}$

*Professor of Law, Harvard Law School.

$\dagger$ Member of the Massachusetts Bar.

1. Our title sufficiently indicates that we are commenting upon part of a larger topic already subjected to profound analysis in 1 WIGMORE ON EvIDENCE (2d ed. 1923) $\$ 265$ et seq. Without laying claim to originality, we hope that narrower examination from a slightly different angle of approach may prove helpful. Our reasons for sclecting this particular part of the general topic are indicated in the text. 2 Canarberchyne on EvXDENCE (1911) §§ 1070b, 1070c, 1075a, 1075c, 1076a, 1077a, and 1078a, should also be scrutinized. Despite differences in language, we are obviously in debt to his thought.

2. For definition of "duly authorized" in this connection see Restatemsens, Aozancy (1933) $\S \S 286,287$.

3. As to this last term see Maguire, Adoptive Admissions in Massachusetts (1929) 14 MAss. L. Q. 62. Wigmore considers adoptive admission vicarious. 2 WroMore on Evidence (2d ed. 1923) \& 1052 (2).

4. The difficulty in setting this transition point is probably more apparent than real. Wigmore says that where silence is "equivalent to an assent to the assertion" of another, it "fixes the party, by adoption, with the other person's assertion, and thus it ceases to be a question of conduct-evidence, and involves a genuine admission in express words." 1 WIGMORE ON EVIDENCE (2d ed. 1923) \& 292 [with cross-references to which may be added $\S 1052$ (2)]. This might be taken to mean that an admission is "implied" only when not explicitly framed in words. We are more attracted to a view that an admission should bo called "express" when it is an intentional manifestation of a proposition of fact or opinion; and should be called "implied" when inferred by the auditor or observer from words or conduct not intended as such a manifestation. Even this definition may not be fully acceptable. Fortunately, we can get along without being utterly meticulous. 
While suppression of evidence is the typical illustration of "spoliation", probably forming the most common basis of the implied admissions which concern us, and thus the foundation of our earlier discussion, many other bases are recognized and require scrutiny. Among these are transfers of property to avoid attachment or execution; flight or concealment to escape arrest or trial; evasive, misleading, or false utterances to influence opponents' actions; fabrication of evidence, subornation of perjury, or perjury itself; intimidation of witnesses, opponents, jurors, or judges; in sum, all sorts of actions calculated to impede or pervert the judicial process. Our title is meant to show that we are seeking only the evidentiary consequences, if any, attributed to such obstructionism. It is not inevitable or indeed always conceded in practice that there should be such consequences. The Supreme Court of Washington suggested purely punitive treatment for a hypothetical attempt to suppress testimony: "A substantial fine for contempt is usually held to be sufficient to compensate an offense against the maxim 'Omnia praesumuntur contra spoliatorem', and the offended dignity of the court." By way of adverse comment upon this dictum, why not distinct concern for the offended pocketbook of the opposing litigant? Even if the threat or actuality of contempt proceedings does keep miscreants in the strait and narrow path as a rule, it furnishes no direct relief to the distressed opponent of a hardened deviator. More than that, many types of obstructionism are considered legitimate or at least insufficiently noxious to offend the "dignity of the court", and therefore run no peril of judicial lightning. A litigant who discreetly refrained from taking the stand or duly claimed privilege against self-incrimination would certainly receive no chastisement. To go even further, we suppose that except in consequence of statute a party would be neither imprisoned nor fined for destroying his account books or his copy of a written contract, at least if he acted before service of process.

Certain it is that courts have not contented themselves with merely punitive process in handling obstructionists. They have vigorously entered the compensatory or remedial field by multiplying devices for direct aid of persons against whom suppression and the like are practiced. Here again, careful distinction is in order. Our inquiry covers part only of the area which such devices occupy. We confine ourselves as narrowly as may be to discussing probative utilization. Relaxation of exclusionary principles to help a hampered party make his case may counter his opponent's spoliation, but does not belong to our topic. Placement of burdens of proof of spoliators and the like does not directly concern us. ${ }^{6}$ These are rules about evidence and not evidence itself.

5. Langley v. Devlin, 95 Wash. 171, 185, 163 Pac. 395, 400 (1917).

6. A recent decision by the Supreme Court of the United States indieates that this 
To a degree, the same may be said as to the erection of presumptions to aid obstructionists' opponents. ${ }^{7}$ But the judges constantly talk about "presumptions" in the instant connection when they really mean "permissible inferences." Since inference is the warp and woof of our topic, we are thus driven to quote presumption language which we regard as spurious. ${ }^{9}$

While this stakes out boundaries of discussion, it is also necessary to say something about possible variations of evidentiary force attributable to implied admissions, or indeed admissions of any sort. The fundamental concepts to be regarded are most commonly illustrated by the expressions "substantive evidence" and "impeaching evidence". Elaborating upon the hypothetical case already suggested, suppose plaintiff declares that in consideration of the delivery of certain goods defendant promised to pay him one hundred dollars and that the goods were duly delivered, but the price not paid. Plaintiff testifies to the agreement. Delivery, however, was entrusted to plaintiff's agent $A$, and $A$ is unavailable. Plaintiff calls $W$, who testifies that after the alleged date of delivery defendant said: "I have plaintiff's goods and owe him one hundred dollars for them". Defendant, testifying in his own behalf, denies both agreement and delivery. If an admission be given substantive effect, the judge may send the case to the jury with an instruction that $W^{\prime} \mathrm{s}$ evidence, if it be believed, will justify although not require a finding of delivery. If evidence of an admission be regarded only as impeaching, the appropriate instruction becomes that the jury must appraise defendant's testimony and, in doing so, may consider the admission as a factor to drop the value of that testimony toward or to zero. But of

highly effective thumb screw must be used with a canny eye on constitutionality. Morrison v. California, 291 U. S. 82 (1934), noted in (1934) 22 CAL. L. REv. 420; (1934) 48 HaRv. L. Rev. 102; (1934) 18 MTNN. L. Rev. 876; and (1934) 8 So. Cal. L. Rev. 136; and discussed by Morgan, Federal Constitutional Limilations Upon Prestmptions Created by State Legislation, Harvard Legat Essays (1934) 323,346 et seq.

7. It is perhaps not entirely superfluous to remark in passing that the problem of effectively disentangling "burden of proof" and "presumptions" is still much alive. For a penetrating analysis and valuable practical suggestions see Morgan, Instructing the Jury Upon Presumptions and Burden of Proof (1933) 47 HARv. L. REv. 59.

8. Thayer, Prelnaminary Treatise (1898) 317, thus puts the distinction: "A rule of presumption does not merely say that such and such a thing is a permissible and usual inference from other facts, but it goes on to say that this significance shall always, in the absence of other circumstances, be imputed to them,-sometimes passing first through the stage of saying that it ought to be imputed." Largely because of Thayer's influence, tho modern tendency is toward precise differentiation. See, for instance, the clean-cut tall in Starkweather v. Conner, 38 P. (2d) 311, 314 (Ariz. 1934). But much of our matcrial comes from old-time cases.

9. Moreover, one essential of the valid presumption is equally necessary to the true inference-namely, reasonable logical connection between foundation or starting point and conclusion or terminal point. See the quotation from Thayer in the preceding noto; also pp. 233 and 244, infra. 
course under this hypothesis the judge would never get around to giving such an instruction, because plaintiff's complete failure to furnish substantive evidence of delivery necessitates a directed verdict against him.

The admission might also have a third possible evidentiary effect, the converse of impeachment. Change the factual hypothesis by assuming the agent $A$ available; let plaintiff, defendant, and $W$ testify as outlined above; and let $A$ also testify that he delivered the goods. Now plaintiff is entitled to go to the jury even if the admission evidence be given no general substantive effect. The judge may use the suggested instruction about impeachment. Further, he may conceivably tell the jury that they must appraise the testimony of plaintiff and $A$, and, in doing so, may consider the admission as a factor tending to maintain the value of that testimony at or near one hundred per cent. This idea is somewhat novel, but far from unprecedented. Under appropriate conditions, for example, the party calling a primary witness may call auxiliary witnesses to testify to his good reputation for truth and veracity, the aim being to persuade the jury to give the testimony of the primary witness its full face value. Such auxiliary testimony is usually called rehabilitating evidence, because considered inadmissible until some attack has been made upon the credibility of the primary witness. The term'rehabilitation does not aptly suggest the proposed employment of the admission now under discussion. Another and perhaps closer analogy is found in cases and statutes admitting evidence of prior statements or action by a witness consistent with his present testimony. ${ }^{10}$ This is often spoken of as self-corroboration. What we are immediately discussing is corroboration by an opponent. Whether or not the concept involves attribution of some "substantive" value to the admission is debatable. The reader will observe, though, a definite top limit to the aggregate value of the admission and the testimony of the corroborated witness-one hundred percent of such testimony's optimum reasonable weight. For lack of an existing term in common employment, we propose to call this conceivable effect of an admission "limited confirmation" as contrasted on one side with mere impeachment and on the other with unlimited or general substantive use. This new intermediate phrase seems to epitomize the legal consequence groped for by frequent talk of "strengthening the offended party's case" with evidence of his opponent's obstructionism. The concept is that such reinforcement may make proper the submission to jurors of an issue which would otherwise be kept from them, or enable a verdict to stand which should otherwise be set aside. We cannot claim that existing opinions precisely

10. Of course this represents an abnormal or minority view. It has, however, been stoutly defended on principle in appropriate situations. See citations and quotations in Morgali and Maguire, Cases on Evidence (1934) 120 n. 1 and 124 n. 3. 
state this concept, but the results of many cases are consistent with its acceptance.

Now until quite recently some great legal scholars asserted that, by and large, prior contradictory statements by witnesses and admissions by litigants had fundamentally identical effect-impeachment alone. ${ }^{11}$ Little was said of the effect we have dubbed confirming, ${ }^{12}$ but substantive effect was distinctly challenged. Nowadays it is recognized beyond doubt that express admissions do have substantive value on the merits. ${ }^{13}$ There is, however, marked diversity of language and results as to the evidentiary significance of implied admissions, and confusion is particularly apparent where obstruction of full and free judicial inquiry furnishes the basis for these inferences. This uncertainty can scarcely be traced to qualms of conscience over the hearsay rule. Laying aside the extreme argument that unintentional implications are not hearsay at all, ${ }^{14}$ we are safe in pointing out that they are less unreliable than intentional expressions in the form of express admissions, because there need be no worry about the sincerity of the declarant or actor. A search of other doctrines than hearsay is necessary to unearth the distinctions now sought.

As a whole, the published opinions are most unsatisfactory. After reading some scores of them, we concluded that any "collection of the authorities" would be an uninformative hodge-podge. ${ }^{15}$ "The typical case vaguely suggests that proof of spoliation or the like has some undefined potency; scarcely ever is there deliberate and rigorous appraisal of its exact legal effect. A good deal of the difficulty very likely runs back to the intertwining of punitive and remedial ideas already noted. Some courts, notably English chancery of the older days, have been full enough of righteous indignation to disregard logic. Others, seemingly

11. Compare $\S 1048$ of Wigmore's superlative work in the 1904 edition with the rovision in the second edition of 1923. Even in 1904 this author conceded the possibility of stretching the principle of declarations against interest to cover such litigants' admissions as were qualified in all respects save unavailability of the declarants. No doubt he would cheerfully have foregone the indefensible requirement that the interest involved must be pecunlary or proprietary, so that his suggestion would explain use of confessions as a direct basis for convictions.

12. See, however, the quotation at p. 243 infra from W. D. Evans' Notes to Pothier.

13. Yet common agreement is lacking as to why this is so. See Professor Chafco's review of Wigmore's second edition in (1924) 37 HARV. L. REV. 513, 518-519. The clash of theories, there indicated does not complicate our present problem.

14. See Morgan, Hearsay and Non-Hearsay (1935) 48 HARv. L. REv. 1138, for what tho present authors believe to be the only really rigorous analysis of the whole definitional problem suggested immediately above.

15. 1 Jones, Compmentaries on Evidence (2d ed. 1926) \& 84 et seq., gives a fair idea of the raw material. Wigmore's text is more illuminating because of his independent thought and language. 
alert to just that risk, have discounted evidence of obstructionism without making articulate the criteria of their action. In particular, there has been at least tacit recognition that juries may damn litigants on general principles, and that, once a verdict is rendered by Philip drunk, effective revision by Philip sober is difficult to achieve. Our next section, treating of the need for deliberate misbehavior to found an implied admission, casts heavy emphasis upon the importance of separating punitive emotion and remedial reasoning.

\section{II}

Intention Contrasted with Negligence as a Basis for Implying Admissions

Having forsworn the idea of loading our footnotes with references, we should at least base our text upon specific controversies. Here is the first: In 1905 and 1907 Missouri legislated to limit freight rates. The railroads affected challenged the validity of this legislation, and had some measure of success in the lower Federal courts. ${ }^{10}$ The Supreme Court of the United States, however, decided against the carriers in 1913. ${ }^{17}$ During the pendency of the suits, higher freight charges than those prescribed by the challenged statutes had been collected. In due course, shippers and consignees applied to recover the excess payments. These applications or some of them were referred to a Special Master. ${ }^{18}$ Before him it appeared that in connection with each shipment the railroad involved had given either shipper or consignee bills or documents sufficiently describing the transaction to permit accurate calculation of overpayments. So many years having intervened, however, much of this documentary material was lost or destroyed before the hearings. Originally, the carriers possessed copies or duplicates. But at least some of the carriers, in normal course of clearing their files, ${ }^{10}$ had destroyed their records for a number of the years involved.

The Special Master found that the routine destruction of records was neither willful, intentional, nor fraudulent making away with evidence, but that there had been negligence in failing to issue such orders as

16. See St. Louis \& S. F. R. Co. v. Hadley, 168 Fed. 317 (C. C. W. D. Mo. 1909), and other litigation there referred to.

17. Missouri Rate Cases, 230 U. S. 474 (1913), with which should be read Mfinnesota Rate Cases, id. at 352 (1913).

18. The cases, still unreported at the time of writing, are part of proceedings entitled Union Trust Co. of New York v. St. Louis, Iron MIountain \& Southern Ry. Co. Through the courtesy of the Special Miaster, Hon. George C. Hitchcock of St. Louis, the authors have had access to copies of the material court papers.

19. There was testimony in behalf of one carrier that it vould bave required 59,036 feet or over 11 miles of linear shelf space to preserve all its station records for the periods in question. 
would have secured preservation of documents necessary to enable the respective carriers to respond to their potential refund obligations. He ruled that each claimant must establish shipments and payment of freight, and must also satisfactorily explain lack of original shipping documents if he sought to rely upon secondary evidence. Having done so, he became entitled to the benefit of the doctrine that omnia praesumuntur contra spoliatorem. The Special Master's characterization of the effect of this doctrine shrewdly embodies various judicial expressions. He mentions re-enforcement of otherwise weak evidence from a plaintiff, and the "presumption" or "strong inference" against a spoliator which will aid in sustaining a "prima facie" case otherwise made out. Under the circumstances of the immediate litigation, he suggests that the doctrine should have the consequence of "shifting the burden of evidence" to the carrier "to show that intervenor [claimant] is not entitled to recover the overcharges as alleged in his petition." These rulings having been carried on exceptions before the District Court of the United States for the Eastern Division of the Eastern Judicial District of Missouri, Judge Faris on April 8, 1933, rendered an oral opinion sustaining the exceptions. This opinion, emphasizing the fact that each claimant had been originally furnished with adequate documentary evidence to establish his claim, asserts that the spoliation principle cannot be developed from mere negligence but only from fraud.

The Judge had authority with him. An Arkansas decision on facts essentially identical says flatly that because "the evidence falls short of showing that appellee [railroad] or its officers intentionally destroyed the papers and records in question for the purpose of preventing them from being used as evidence", the trial court did not err "in refusing to apply the spoliation doctrine . . . ."20 Instances of looser language are naturally discoverable, ${ }^{21}$ but we have not turned up a single opinion

20. Gallup v. St. Louis, I. M. \& S. Ry. Co., 140 Ark. 347, 355, 215 S. W. 586, 588 (1919). Cf. In re Campbell's Will, 100 Vt. 395, 402-403, 138 Atl. 725, 728, 54 A. L. R. 1369,1373 (1927), and 102 Vt. 294, 298, 304, 305-306, 147 Atl. 687, 691-692 (1929), whero the signatures and attestation clause of an instrument propounded as a will had been torn off and destroyed after the death of the alleged testatrix. The court insists that a prosumption of due execution arose if such action had been intentional and illegal, even though innocent and bona fide. At one point the first opinion slips into talk of "constructive fraud", which seems unfortunate as suggesting an artificial implication of law rather than a natural implication of fact. But the conclusion is quite defensible. Why did the destroyer bother to make away with part of the document unless he supposed that it constituted or evidenced due execution? Such being the line of thought, however, why emphasize illegality?

21. E.g. Middleton v. Middleton, 188 Ark. 1022, 1026, 68 S. W. (2d) 1003, 1006 (1934): "Where some written instrument, which is a part of the material evidence in a caso, has been destroyed, the presumption arises that, if it had been produced, it would have been against the interest of the spoliator, and, where the instrument destroyed is of such naturo as to destroy all evidence, there follows a conclusive presumption that, if produced, it 
deliberately superposing the consequence of an implied admission upon a basis clearly involving nothing beyond oversight or carelessness.

Of course an empirical approach of this sort is not generally to be recommended, and we gladly shift from dogmatism to deliberation by examining a group of due process cases straddling the boundary line between punitive and compensatory procedure. Hovey v. Elliot $t^{22}$ reduces itself in essence to discussion of the propriety of striking out answers and entering a final adverse decree because of defendants' contempt in refusing to pay into court a sum of money immediately in controversy. This stringent judicial act was held to have violated due process, as amounting to condemnation without hearing. White, J., wrote the opinion. Less than twelve years later, the same learned judge wrote a majority opinion to the effect that under a state anti-trust act an allegedly offending corporation might constitutionally have its pleadings stricken out and be subjected to judgment for penalties of $\$ 10,000$ in consequence of its refusal, without bona fide effort or any reasonable showing of inability, to produce certain witnesses for examination and certain books for inspection. ${ }^{23}$ Hovey $v$. Elliott was distinguished because it "involved a denial of all right to defend as a mere punishment." In the second case the legislature had exerted its "undoubted right to create a presumption of fact as to the bad faith and untruth of an answer begotten from the suppression [of] or failure to produce the proof ordered, when such proof concerned the rightful decision of the cause. ... In a sense, of course, the striking out of the answer and default was a punishment, but it was only remotely so .... [Far from denying due process, this decision preserved it] by the presumption that the refusal to produce evidence material to the administration of due

would have established the claim of the adversary of him who destroyed the instrument where it is shown that the destruction was willful." Grammatically, this involved sæntence may be read as affing the requirement of willfulness only to the latter "conclusive presumption" and not to the unadorned presumption which precedes. However, there was not the least doubt that the documentary destruction immediately under considerntion had been intentional. Also, this case arose in the very jurisdiction which produced the Gallup case (supra note 20 ) fifteen years before, and cites the earlier case without the least hint of disapprobation.

22. 167 U. S. $409,412-414,418-419,446$ (1897), most of the intervening pages containing a laborious review of English and American precedents.

23. Hammond Packing Co. v. Arkansas, 212 U. S. 322, 336 et seq., 341-342, 346 et seq, 15 Ann. Cas. 645 (1909). Fuller, C.J., and Peckham, J., diesent without opinion. See 3 Wigmore on Evideice (2d ed. 1923) $\S 1859$, and both this section and $\S 278 \mathrm{n}$. 43 , in the Supplement of 1934 .

24. 212 U. S. 322,350 (1909), on which page the opinion repudiates the idea of differentiating the cases because the trial court lacked express statutory authority in the earlier litigation, and possessed such authority in the later litigation. But see Walter Cabinet Co. v. Russell, 250 III. 416, 422, 95 N. E. 462,464 (1911), apparently insisting upon the necessity of legislative aid to support such an order as that in the Eammond case. 
process was but an admission of the want of merit in the asserted defense."25

Characterization of the principle involved as a "presumption" may cause momentary hesitation to the stickler for exact definition. Professor J. B. Thayer and his disciples have trained us to think of presumptions as conditional imperatives, requiring specified findings of fact only in the absence of rebuttal, and the imperative outlined above seems quite unconditional. ${ }^{26}$ But actually an opportunity for rebuttal is afforded. Orders to expunge pleadings are not entered ex parte. "The recalcitrant party," says the New York Court of Appeals, "has, then, had opportunity to meet the charges at a fair hearing. He rejects that opportunity when he willfully disobeys the order of the court for the production of evidence .... [The court may exercise its power to strike out an answer and enter judgment pro confesso] only in aid of its function to determine the truth of the charges made after due consideration and after opportunity for a hearing accorded to all parties." ${ }^{27}$ At any time before or even during that hearing, rebuttal is possible through production of the suppressed evidence. The really important point for us is that the courts require an adequate showing of rational connection between the withholding of evidence and the conclusion of guilt or culpability. This reiterates a constitutional doctrine made painfully familiar to state legislatures in recent years. Unless the propositions of fact forming the basis of statutory presumption have some logical tendency to establish the conclusion; the presumption violates due process..$^{28}$ So, to carry the doctrine forward in more specific detail, it seems perfectly sound that a defendant who suppresses evidence with respect to one only of several issues may not in consequence be precluded from contesting the other issues. This is neatly illustrated by a proceeding to recover damages for fraudulently inducing the sale of corporate stock at one-tenth of its true value, where defendant set up (1) a general denial, (2) accord and satisfaction, and (3) a sealed release. During introductory proceedings defendant failed to disclose evidence relating to the value of the stock and nothing else. The trial court under an empowering statute struck out the entire answer and entered

25. 212 U. S. $322,350-351$ (1909).

26. See the talk of irrebuttable presumption in (1925) 10 CoRN. L. Q. 234, 241.

27. People v. George Henriques \& Co., Inc., 267 N. Y. 398, 403, 196 N. E. 304, 305306 (1935).

28. Morgan, supra note 6, at 324-5. On principle, the same doctrine should apply to judicially created presumptions. "It must however," says 2 Evans' Poturen (1806) 337-338, "be remembered, that whatever impropriety there may be in any such suppression or fabrication, the effect of it ought only to be applied to the decision of the fact in dispute, and a punishment should not be inflicted under the name of a presumption, when the fact supposed to be presumed is not in truth believed". 
judgment for plaintiff. The order was modified on appeal to prevent defendant only from contesting the issue of value, and to permit contest of the other issues. ${ }^{29}$

Simple as all this is when thus outlined, we think it of fundamental importance to our discussion. In the immediate connection, the demand for logical relation or relevancy between the misconduct and the procedural consequence fully justifies our tentative empirical conclusion that true implied admissions arising from "spoliation" and the like must involve an element of deliberation or intention, negligence by itself being insufficient. For obviously our logical relation is traced through the well-known formula: The litigant's conduct indicates a belief relevant and detrimental to some feature of his case; therefore he holds that belief; therefore his case in this feature is defective. ${ }^{30}$ But if the litigant's conduct results only from happy-go-lucky carelessness, and not from specific motive or intention to achieve a specific end, the whole backbone of the formula breaks. The necessary showing of belief is lacking.

\section{III}

\section{Implied Admissions as General Substantive Evidence}

Revert to the hypothetical sale of goods case already sketched and imagine that on the issue of delivery the plaintiff does not give enough ordinary evidence to get him to the jury. Defendant, who has books of account and who knows the identity and whereabouts of $A$, the delivery agent, puts in no evidence whatever, and then moves for a non-suit or directed verdict. Plaintiff argues that he is entitled to the aid of a probative inference because of his adversary's reticence. Assuming that

29. Feingold v. Walworth Bros., Inc., 238 N. Y. 446, 454-455, 144 N. E. 675,678 (1924), noted in (1925) 10 ConN. L. Q. 234, and (1925) 19 IrI. L. Rev. 594. Two judges dissented on the ground that there was no adequate showing of willful suppresion. The main opinion says: "The punishment is for withholding proof and is properly limited to excluding what the proof presumptively establishes .... The power to punish is limited by the presumption which attaches to the suppression of the evidence suppressed." It may be added that there were several defendants here, and that the order of diccovery was directed to and disobeyed by some of them only. It was held improper to strilse out the pleadings of the others. Cf. the later case of People v. George Henriques \& Co., Inc, 267 N. Y. 398,196 N. E. 304 (1935), where failure to disclose evidence relating to a certain stretch of time came first, then a case was shaped exactly covering the period of nondisclosure, next the answer in that case was stricken out, and finally the court without testimony made nineteen separate findings of fact and twenty-four separate conclusions of law and entered a final judgment of injunction and liquidation. This judgment was reversed. See also the brief chapter on this topic in Raglasi, Discoverz BEFone Trir (1932) 154 et seq., indicating some looseness in the State and even the lower Federal courts. For an analogous limitation of consequences under the "clean hands" doctrine consult Keystone Driller Co. v. General Excavator Co., 290 U. S. 240, 245 (1933).

30. 1 WigMrore, Eumence (2d ed. 1923) $\$ 267$. 
plaintiff has the burden of proof, the standard result is the granting of defendant's motion. Over and over again it has been ruled that a party in the defensive position is not to be prejudiced for holding his fire when an opponent has failed to make what is commonly called for convenience a prima facie case. ${ }^{31}$ But now suppose we add to plaintiff's evidence a showing that after action brought defendant either (1) destroyed an account book or (2) spirited the key witness $A$ out of the jurisdiction.

In deciding whether this auxiliary showing should get plaintiff to the jury, we strike at once the problem of logical connection or relevance opened by the preceding section. It is a hard problem, harder indeed to grasp and solve than straightaway hearsay questions. For hearsay, while it has to fight around or through a definite exclusionary rule, is typically in assertive form and therefore canalized. One knows where it will tend to carry the jury, if admitted, and can easily decide whether it has logical bearing upon the case. The extra-judicial assertion: "I killed $X$, has manifest relevance if the issue be whether the speaker committed homicide, or whether $X$ is dead. Its irrelevance on many other issues is equally manifest. But the stuff from which implied admissions may be made frequently does not flow between canal banks. Its possibilities are rather those of a blob of mercury tossed on a table top. Coherence and course of motion are both doubtful. Perhaps the triers of fact may not feel able to draw any inference from a mere showing that defendant "destroyed an account book". How do they know whether the act was purely careless or intentional? What was in the book? Household accounts or something about the deal with plaintiff? Until there has been a preliminary showing on all this, we cannot even make a decent start toward inferring anything against the spoliator. Wigmore thus explains the common doctrine that where an opponent has destroyed a document some evidence of its contents must precede

31. Middletown Trust Co. v. Bregman, 118 Conn. 651, 657-658, 174 Atl. 67, 70 (1934); Condon v. Schoenfeld, 214 Ill. 226, 230-231, 73 N. E. 333, 335 (1905); Stimpson v. Hunter, 234 Mass. 61, 65, 125 N. E. 155, 157, 7 A. L. R. 1067, 1070 (1919); and Galbraith v. Busch, 267 N. Y. $230,236,196$ N. E. 36,39 (1935), where the dissenter seems to quarrel less with the principle at large than with its immediate application. Out of a crowding multitude of cases we cite typical ones from representative jurisdictions. Some remarks by the usually careful Hammond, J., in D'Addio v. Hinckley Rendering Co., 213 Mass. $465,468,100$ N. Es 647,648 (1913), are profoundly puzzling: "We are not dealing with a case where at the close of the plaintiff's testimony the presiding judge rules that thero is no case for the plaintiff, or in other words that the defendant is not called upon to put in his evidence. In such a case there are no presumptions to be drawn against the defendant for his failure to explain whatever may be used against him. The presiding judge in substance rules that there is no need of explanation on his part; and that is enough. In tho present case the ruling was made at the close of the whole evidence . . . . If thero was anything in the evidence produced by the plaintiff which bore against the defendant, it was called upon to explain and it had the fullest opportunity to do so." The most natural interpretation of this passage is that a trial judge who overestimates the force of evidence 
the creation of a hostile inference. ${ }^{32}$ Nor is this the only point of relevancy which must be watched. Assuming all the foregoing doubts cleared away, why did the defendant act? His object, proper or improper, may have been quite remote from that of hampering the immediate inquiry. ${ }^{33}$ In electing between two or more appropriate alterna-

already put in may cast upon defendant a damaging obligation of disproof, although if be had properly appraised the evidence no such obligation would have been created. This seems dubious doctrine. Simes v. Rockwell, 156 Misss. 372, 374, 31 N. E. 484, 4\$5 (1392), is also puzzling. Here one issue was the authority of defendant's husband to represent her in a business transaction. The husband testified, but with marked circumspection. The court remarks that the spouses were the only ones who bnew the full truth. "Facts appeared at the trial which justified the court and jury in believing that the defendant, conniving with her husband, deliberately attempted to suppress this evidence. It was not merely an absence from the trial, or a failure to call witnesses, which could not prejudice a defendant unless a case was first made out requiring an answer, but it was an attempt to deprive the plaintiff of the testimony of the witnesses who knew the fact in dispute. It indicated a belief on the part of the defendant that the testimony, if given truly, would be valuable to the plaintiff and damaging to berself. The suppresion of important evidence is always a fact to be weighed against the party suppressing it . . . ." The opinion then cites a case where there was evidence that a party had suborned a witness. Cross v. Bell, 34 N. H. 82, 88-89 (1556), stating the general rule according to our text, accepts a very flimsy prima facie case.

32. 1 Wigarore on Evidesce (2d ed. 1923) \$291 at pp. 603-604. See Gage v. Parmelee, 87 III. 329, 344 (1877): "There is but conjecture, that the books, if produced, might furnish evidence in support of the allegations of the bill." Also Hay v. Peterson, 6 Wyo. 419, 438, 45 Pac. 1073, 1078, 34 L. R. A. 581, 589 (1596): "But some general evidence of such parts of their contents as are applicable to the case must first be given, before any foundation is laid for any inference or intendment on account of their non-production." Farulla v. Ralph A. Freundlich, Inc, 155 N. Y. Misc. 262, 277, 279 N. Y. Supp. 223, 245 (Sup. Ct. 1935) (accord). Cf. Login v. Waisman, S2 N. H. 500, 502, 136 At. 134, 136 (1927), where a witness who had disappeared, allegedly at defendant's instigation, was apparently quite ignorant of the facts bearing upon one vital issue; also People v. MIeWhorter, 4 Barb. (N. Y.) 438,441 (1S48), where witnesses not called by defendant to sustain an alibi might have been asleep at the vital time.

33. In Gage v. Parmelee, 87 Ill. 329, 342 (1877), the spoliator claimed to bave acted on hearing a threat "to file a bill . . . for the purpose of exposing his business to the public." In Hay v. Peterson, 6 Wyo. 419, 433-434, 435, 440, 45 Pac. 1073, 1076, 1077, 1078,

34. I. R. A. 581, 585-586, 587, 590 (1896), the explanations included stupidity and a supposed duty to a deceased employer. In both cases the books or some of them had bean produced for examination before destruction. See also Mrastin v. Noble, 157 Fed. 505, 512-513 (C. C. A. 8th, 1907), refusing to allow hostile presumption or inference where business papers were destroyed intentionally but partly "as useless and cumbersome matter by the housewife" and generally "in line with the habit of many unmethodieal persons." Cf. Longacre v. Yonkers Ry. Co., 236 N. Y. 119, 125-127, 140 N. E. 215, 217-215 (1923), where defendant explained that a witness not called had given untrue testimony on an earlier occasion. IIerrill v. St. Paul City Ry. Co., 170 Mrinn. 332, 335-337, 212 N. W. 533,534 (1927), interestingly discusses the ambiguity of inference from failure to call medical witnesses. It is a matter of common knowledge that criminal defendants frequently keep off the stand to avoid the generally devastating effect of testimonial impeachment by proof of former convictions. Robert P. Reeder, Comment Upon Fuilare of Accused to Testify (1932) 31 Mircr. L. Rev. 40, 56; Andrew A. Bruce, The Right to Comment on 
tive inferences, nothing short of omniscience could make the choice infallible.

Here in particular a possible distinction may be noted between destruction of an account book and efforts to prevent a witness from giving testimony. Normally, the documentary evidence will be unequivocal and comparatively reliable. Deliberate making away with it by defendant, relevance of the contents having been established, easily justifies an inference that he believes the truth inimical to his case. This is not nearly so sure as to the witness. For "witnesses see facts differently, and almost every trial of an issue of fact demonstrates that they may testify honestly and still be mistaken." ${ }^{134}$ There is a ponderable chance that in dealing with the witness the motive may have been to suppress untruth. But we do not believe this distinction sound. Admittedly determinations of fact in human tribunals are not based upon divine revelations of absolute truth. Nor, for litigious purposes, is "truth" what either party sincerely believes. Courtroom truth is what a jury or the judge finds after full and fair presentation of evidence. The correct hostile inference from efforts to prevent a witness from giving testimony is that the offending party, by disclosing unwillingness to let the tribunal use human recollection and all the other materials relevant to the shaping of courtroom truth, gives support to the conclusion that a proper finding would be against him. ${ }^{35}$

Coming through these preliminary points to the fundamental question of using implied admissions for general substantive purposes, we find plenty of real or apparent disagreement. New Hampshire has expressed the view that even bribing a material witness to absent himself is "conduct . . . chiefly persuasive as distinguished from probative

the Failure of the Defendant to Testify id. at 226, 232. Cf. 1 Wigmore on Evidence (2d ed. 1923) § 194a, and 1934 Supplement, §§ 194, 194a, 194b; also Pcople v. Pignataro, 263 N. Y. $229,235,188$ N. E. 720,722 (1934); and Professor Hinton's acute comment in (1926) 21 IrL. L. Rev. 396. In Fross v. Wotton, 44 P. (2d) 350, 354 (Cal. Sup. 1935), the relevancy of claims of privilege against self-incrimination is carefully worked out. On other reasonable grounds as well, there is often cause to deny hostile inferences from criminal defendants' failure to testify. (1935) 94 A. L. R. 706-708. See generally (1926) 74 U. of PA. L. Rev. 746.

34. Harrison v. Harrison, 124 Iowa 525, 527, 100 N. W. 344, 345 (1904), holding that evidence of litigant's activities with respect to the witness might properly be "left for the consideration of the jury" but did not justify the view that the litigant had implledly admitted his cause was without merit or unjust. Cf. note 58 infra.

35. Cf. Láw v. Woodruff, 48 III. 399, 401 (1868), a breach of promise case where plaintiff put in defendant's letters to her, but he refrained from putting in hers to him. The court charged about a presumption that plaintiff's letters contained evidence against defendant, or he would not have withbeld them. This was disapproved. "If such wero the legal conclusion, it would place almost any single man at the mercy of an artful and designing woman .... Such facts should be left to the jury, as practical men, to weigh, consider and determine what they prove, if anything." The female of the species ... 1 
in its effect, and . . . cannot take the place of proof of necessary facts."100 New York, starting with at least some inclination in the other direction, has more recently produced a good deal of judicial language consistent with this view. ${ }^{37}$ As on most contested topics, there is much use of weasel words. A common and highly objectionable method of expression "presumes that the testimony of the missing witness, or the contents of the missing document, would have been unfavorable to the suppressing party if adduced."38 The New Hampshire court jeered at this as a character-

36. Login v. Waisman, 82 N. H. 500, 502, 136 Atl. 134, 136 (1927), and cee caces from this and other States collected in (1931) 70 A. L. R. 1320, 1326.

37. In Gordon v. People, 33 N. Y. 501, 506-507, 508-509, 513 (1865), a murder case turning upon identification, the judge charged that defendant's failure to call available witnesses to meet an apparently strong case made by the prosecution caused what was before not absolute to ripen into certainty, and also caused "circumstantial evidence of this sort" to become "of a conclusive character". This was held too strong, but the majority say: "The absence of such [rebuttal] evidence, especially, when it appears to be in the power of the prisoner to furnish it, creates a strong presumption of his guilt, a strong inference against him, and is a circumstance greatly corroborative of the truth of the evidence given upon the other side. In a doubtful case, it would justify the jury in resolving the doubt against him." The dissenter, who wished to sustain the charge, was attracted by a quotation from Beccaria, the criminologist: "Imperfect proofs, of which the aceused, if innocent, might clear himself, become perfect." But see Bleecher v. Johnston, $69 \mathrm{~N}$. Y. 309, 313 (1577), and Schwier v. New York Central Rr. Co.. 90 N. Y. $5 \div 3.564$ (1892), both very frequently cited and both saying or suggesting that a party's failure to call a witness is not evidence against that party of the existence of any fact. Mreyer v. Minsly, 128 App. Div. 589, 590, 112 N. Y. Supp. 860, 861 (1st Dep't 108), disapproves 'a charpo that a jury "may find from [defendant's] presence and such failure to put him on the stand, that if he were put upon the stand he would testify in favor of the plaintifr". The jury might properly infer "that his testimony would not be favorable to himself"; but "silence of the party refusing to take the stand is not to be accepted as afirmative corroborative evidence in favor of his opponent"; such silence is not "a positive admission of the truth of the story told by the plaintiff . . . . The distinction is a substantial one ...." Perlman v. Shanck, 192 App. Div. 179, 183-184, 182 N. Y. Supp. 767, 770 (1st Dep't 1920), and Polachek v. New York Life Ins. Co., 147 1ifise. 16, 22, $263 \mathrm{~N}$. Y. Supp. 230, 239 (Sup. Ct. 1933), aff'd. without opinion 240 App. Div. 1028, 263 N. Y. Supp. 995 (1st Dep't 1934), summarize earlier cases.

38. Smith v. Firestone Tire \& Rubber Co., 119 Conn. 483, 488, 177 Atl. 524, 527 (1935), failure to produce order book permitted inference that book "syould have contained information antagonistic to the contention of the defendant"; Houser v. Austin, 2 Idaho 204, 212, 10 Pac. 37, 42 (1886), hiring witness to leave country raises presumption that if truth appeared it would be against the misbehaving litigant; Central Stock \& Grain Exchange v. Board of Trade, $196 \mathrm{Ml} .396,406-407,409,63 \mathrm{~N}$. E. 740, 744, 745 (1902), refusal to produce documents and answer questions under claim of privilege causes presumption that evidence if produced would be unfavorable (one judge dissenting, because party had been called by opponent instead of taking stand in his own behalf); Parsons v. Mrartin, 11 Gray 111, 113, 115 (Mass. 1858), talk about "strong presumptions . . . pregnant suspicions that the truth, if developed, would operate against him"; D'Addio v. Hincliley Rendering Co., 213 Mass. 465, 469, 100 N. E. 647, 648 (1913), if party can but does not explain matters apparently telling against him "it properly may be presumed that no truth-• ful explanation will help him"; and Tremaine v. H. K. Mulford Co., 317 Pa. 97, 106, 176 
ization of substantive proof: "Had the plaintiffs offered to show that there was unsubmitted evidence in their favor which would strengthen their case, it [i.e. the offered showing] would have been excluded as incompetent .... This is no more than saying that proof must rest upon evidence and not upon its absence." ${ }^{130}$ Massachusetts, at least, displays great fondness for telling the jury to draw such inferences as they see fit, thus avoiding any particular clarity, but certainly making possible the substantive use of the implied admissions involved. ${ }^{40}$

Turning to litigation where inferences from obstructive conduct have unquestionably been given substantive effect, or where clear willingness to permit such effect has been evinced, ${ }^{41}$ we think that detailed exposition of one of the most cited American spoliation cases-Pomeroy $v$. Benton $^{42}$-will be more useful than abstract discussion. Pomeroy and Benton had been partners until the latter bought out his associate. Later Pomeroy sought an accounting from his former partner. Ostensibly the partnership had been in the dry goods business. The defendant,

Atl. 212, 216 (1935), quotes Corpus Juris on inference or presumption that unproduced evidence "if . . . given . . . would have been detrimental." Cf. Wilson v. Grace, 273 Mass. 146, 152, 173 N. E. 524, 527 (1930). And see Cat. Code Crv. Proc. (1931) $\S 1963$ (5), listing among rebuttable presumptions: "That evidence willfully suppressed would be adverse if produced."

39. Stocker v. Boston \& Maine Rr., 84 N. H. 377, 380, 151 Atl. 457, 458, 70 A. L. R. 1320,1324 (1930).

40. Whitney v. Bayley, 4 Allen 173, 175-176 (Mass. 1862); McKim v. Foley, 170 Mass. $426,427,49$ N. E. 625 (1898), where no fewer than four inferences, only one of them adverse, were conceivable as a result of failure to call expert witnesses, and the upper court suggested the wisdom of minimizing unjust inference by exercising discretionary restrictive power; Howe v. Howe, 199 Mass. 598, 603, 604, 85 N. E. 945, 947, 948 (1908) (several variant phrasings); and Little v. Massachusetts N. E. St. Ry. Co., 229 Mass. 244, 118 N. E. 245 (1918). See also Reetz v. Mansfield, 119 Conn. 563, 567, 178 Atl. 53, 55 (1935).

41. Downing v. Plate, 90 IIl. 268,273 (1878), states and applies the doctrine "that where a party has wrongfully destroyed the only written evidence of the fact which is in existence, his unsupported evidence, as to the contents of that writing, shall not be allowed to prevail against the testimony of any other witness,-for the presumption is that the paper, if it could be produced, would corroborate the other witness." Amite Bank \& Trust Co. v. Standard Box \& Veneer Co., 177 La. 954, 966-967, 149 So. 532, 536 (1933), cnunciates very similar doctrine. Cf. Colvin v. Kokusia \& Kaisha, 72 F. (2d) 44,46 (C. C. A. 5th, 1934) ; Starkweather v. Conner, 38 P. (2d) 311, 314 (Ariz. 1934); People v. Spaulding, 309 Ill. 292, 298, 305 et seq., 141 N. E. 196, 199, 202 (1923) (evidence that defendant in murder case bad killed the most important witness of the crime for which he was being tried); Phelps v. Commonwealth, 255 Ky. 655, 659, 75 S. W. (2d) 217, 219 (1934); Berenson v. Conant, 214 Mass. $127,131,101$ N. E. 60,61 (1913) (failure to testify to repel accusations against motives and conduct); Attorney-General v. Pelleticr, 240 Mass. 264, 316,134 N. E. 407,423 (1922) (very positive language under strong circumstances somewhat analogous to those of preceding case); Merchant v. Houston Gas \& Fuel Co., 78 S. W. (2d) 656,660 (Tex. Civ. App. 1935). See also the quotation in note 21, supro.

42. 77 Mo. 64 (1882). See also Gaugh v. Gaugh, 321 Mo. 414, 454, 11 S. W. (2d) 729,748 (1928). 
however, was found to have taken fliers in wet goods-whisky and high-wines-using firm money and concealing the collateral profits. The only full record of this alcoholic venture he kept in a so-called private account book. Because "he did not wish any one to look into his private accounts", defendant before trial tore out and burned the leaves having to do with the whisky transactions. Thus it became "impossible to tell what was the amount . . . realized by reason of his fraudulent practices .... How often the money defendant invested ... was turned over, was re-invested, never will be known." 14

This is a hard situation, verging on the non-justiciable. Plaintiff prevailed, but only by vote of a bare majority. Their reasoning begins with the finding "that defendant destroyed that book after suit brought, for the deliberate and sole purpose of cutting off investigation into the magnitude of his operations in whisky." "14 Thus we get a basis for the desired inference: - His action indicates belief that he was deeply in the wrong; therefore he did so believe; therefore he was deeply in the wrong. Then the opinion speaks out flatly with an attribution of probative consequences to the spoliation: "It is because of the very fact that the evidence of the plaintiff, the proofs of his claim or the muniments of his title, have been destroyed, that the law, in hatred of the spoiler, baffles the destroyer, and thwarts his iniquitous purpose, by indulging a presumption which supplies the lost proof, and thus defeats the wrongdoer by the very means he had so confidently employed to perpetrate the wrong."245 Next came the real rub. How many dollars should plaintiff receive? The judgment was not a simple choice between black and white, conviction or acquittal, ouster or continued possession."5 It contained a problem of measurement. The court seized eagerly upon the delightful tale of the chimney-sweep's boy and the artful goldsmith. ${ }^{47}$ There, however, the tribunal had helpful standards in (1) the size of the socket from which the jewel had been abstracted and (2) expert testimony as to the value of a jewel of the finest water which would fit the socket. No such precise objective limitations could be laid down in the partnership accounting case. The capacity of Missouri and adjoin-

43. 77 Mo. $64,71,84-85$ (1882).

44. 77 Mo. 64, 85 (1882).

45. 77 IIo. 64, 86 (1882). The leading case of Clark v. Turner, 50 Neb. 290, 301, 69 N. W. 843, 846, 38 L. R. A. 433, 454 (1897), says: "It would certainly be very dangerous to extend [the maxim about spoliation] so far as to relieve a party charged with proving the contents of a written instrument from all obligation to produce some evidence of a competent character...."

46. For a very strong "black and "white" case, see Middleton v. Mifiddleton, 185 Arl. 1022, 68 S. W. (2d) 1003 (1934), where spoliative destruction of an alleged holographic will was held to justify disregard of a statute requiring proof of signature and bandwriting by three disinterested witnesses. Three justices dissented.

47. Amory v. Delamirie, 1 Stra. 505 (K. B. 1722). 
ing States for consumption of alcoholic beverages during the time covered by defendant's liquor dealings was a hopelessly vague and extravagant top limit. For a measure of recovery, then, the court had recourse to plaintiff's petition alleging that defendant's net profit from misuse of firm money had been $\$ 200,000 .^{48}$ This had some support in a line of English cases dealing with disputes about the contents of destroyed or suppressed wills, deeds, and the like. At their strongest these cases may be interpreted as assuming, after due proof of spoliation, "that the contents of the thing spoliated are what they have been alleged to be ...."40

Now of course this suggestion that the spoliator shall be taken to confess liability to the maximum of his opponent's claim carries our thought back to the device of striking out defensive pleadings and entering judgment when proper discovery is refused. But, if we keep away from vindictiveness and stick to logic, some discriminations may be made. Obstinately continued non-disclosure after the full scope of an opponent's allegations is realized may well be an implied admission that these allegations are at least $100 \%$ true. So may destruction of evidence after such realization, and it will be remembered that the partnership-whisky case contained a finding of destruction after suit brought. Defendant in this very case, though, testified that his spoliation occurred two and one-half years before plaintiff filed his petition. ${ }^{50}$ Had this date been accepted, and had there been no evidence that plaintiff otherwise brought home the specifications of his claim before the spoliation occurred, reasoning that defendant had admitted such claim to the full would be distinctly flimsy. ${ }^{51}$ In truth, the partnership-whisky case contains an over-load of punitive fervor. ${ }^{52}$ It had first come to the appellate

48. 77 Mo. 64, 67, 88 (1882).

49. This description is Lord Eldon's in Barker v. Ray, 2 Russ. 63, 73 (Ch. 1826), and is accompanied by expressions of doubt as to the propricty of carrying the doctrine to such extremes. Other lines of citation in the case under discussion are not so pointed, and it should be remarked that some plaintiffs in the English documentary controversies were able to produce more or less convincing secondary evidence. An American authority, Hudson v, Fiudson, 287 Ill. 286, 299, 122 N. E. 497, 502 (1919), speaks thus of the effect of destruction of a deed by the grantor: "Having destroyed it, it is he who must suffer the inconvenience from the loss of the evidence and not the grantee. When the grantce has proved that the deed was executed, the presumption is that it conveyed the highest title it could convey,-that is, a fee simple." Under American conditions at least, is not this a natural "presumption"-quite likely the court really means "inference"-with respect to the habendum of any ordinary deed?

50. 77 Mo. 64, 66, 71 (1882).

51. Here it is well to bear in mind the principle, amusingly illustrated by "Joannes" v. Bennett, 5 Allen 169, 172 (Mass. 1862), that the spoliative destroyer of a document may not give secondary evidence of its contents.

52. And so, it seems to us, do many opinions suggesting a distinction between (1) mere non-disclosure and (2) destruction, permitting more radical inference from the latter. E.g. Bleecker v. Johnston, 69 N. Y. 309, 311 (1877). Here, though, it can be argued that 
court some eight years earlier, on which occasion the tribunal expressed vigorous distaste for defendant's operations. ${ }^{.3}$ Upon reappearance it received a hot welcome. For evidence of this we need only to observe that the $\$ 200,000$, originally made the measure of recovery, contained assumed profits from side dealings in other commodities than alcoholic beverages. But the spoliation affected liquor accounts only. This being called to the court's attention on rehearing, the majority backed down and cut the whisky award to $\$ 100,000$ minus a further adjustment in the interest of a third party. Even more significant, the $\$ 100,000$ figure was reached from considering the testimony of "one or more witnesses ... to the fact that they understood from [defendant], that his profits on the whisky on hand would be $\$ 100,000$ " and "other testimony in the record, tending to show the same fact." A lawyer minimizing this case might well contend that the judgment came to rest on defendant's express admissions, and not at all on the inference or presumption from spoliation. The contention on the other side can hardly go beyond a claim that destruction of the account carried some weight along with plaintiff's other evidence. This whittling down of the significance of spoliation certainly is an anticlimax, forced by practical difficulties likely to give other courts pause.

\section{IV}

\section{Implied Admissions for Purposes of Limited Confirmation}

In the early days of the nineteenth century, W. D. Evans wrote as follows:

"That a party shall be actually forced to produce the evidence, so as to be punished for refusal, is a proposition totally unwarranted by authority, and I suppose that is not what was meant by the expressions about quoted [from Lord Mansfield in Roe v. Harvey], and what is said respecting leaving the refusal as a presumption to the jury, should it [sic] be received with considerable qualification; for it cannot be admitted that such a presumption should stand instead of all other evidence, and supply the total deficiency of proof. It is only in weighing the effect and substance of evidence, in its nature adequate to the support of a fact in question, that

the irrevocable act of destruction implies greater apprehension. When a similar distinction is taken between bribing a witness and merely persuading him to stay aw3y, the punitive element again inevitably suggests itself. Gregory v. Sorenson, 214 Iowa, 1374, 1379-1380, 242 N. W. 91, 94 (1932). But here a secondary explanation lies in the greater risls of bribery and the consequent likelihood that it would be shunned except when impentive. Such reasoning is suggested by 2 Evaxs' Potmer (1806) 337, which continues with the warning quoted in Note 28 , supra.

53. Pomeroy v. Benton, 57 Mo. 531, 543, 549 (1874).

54. 77 Mo. 64, 90 (1882). Haid v. Prendiville, 292 Mo. 552, 565-566, 238 S. W. 452, 455 (1922), also "roars so loud and thunders in the index", but ends with a noise more like that of a penny whistle. 
the jury can take into consideration the opportunity allowed to the opposite side of contradicting the evidence if false, or of destroying the inference from it, if erroneous, and thereby conclude that evidence, otherwise suspicious, is true: or that an inference, otherwise slight and feeble, is correct." 55

If such a cautionary statement seemed in order when an opponent at common law was not compellable either to testify or produce documents, ${ }^{56}$ unfriendly inference or presumption thus being often the only available device for exerting pressure, it should be taken still more to heart in these days of comprehensive testimonial compulsion. Evans' views have indeed caught the eye of our American bench. ${ }^{57}$ But neither he nor his judicial converts seem to give much more than a sincere expression to an instinctive attitude. The call for explanation remains unanswered.

One step, at least, is easy. There are cases where it would be plainly improper from a logical point of view to allow an implied admission greater probative effect than is comprehended by our term limited confirmation. Suppose the defendant in our long-enduring sale of goods hypothesis tries hard to hide his account book but fails, and the plaintiff puts the book in evidence; or suppose that the same defendant bribes the delivery agent $A$ to leave the State; but $A$ turns up at the trial and testifies favorably for the plaintiff. Thus the jury get the very evidence about the purport of which presumptions were to be built or inferences drawn. Occasion for such guesswork has vanished. An extremist might say that evidence of defendant's misconduct should not be receivable even for confirmation. "When the witness is in fact present and testifies," despite efforts to keep him away, "the jury has before it his full

55. 2 Evans' Pothmer (1806) 169. See also id. at $33 \%$.

56. 4 Wigmore ON Evidence (2d ed. 1923) § 2217.

57. Evans is quoted or paraphrased in Bleecker v. Johnston, 69 N. Y. 308, 312 (1877), and Arbuckle v. Templeton, 65 Vt. 205, 211-212, 25 Atl. 1095, 1097 (1892); also in (1926) 6 B. U. L. REv. 50. The New Hampshire cases cited in Notes 36 and 39 stupra obviously point the same way; see, too, the additional New York opinions cited in Note 37, supra; People v. Deitsch, 237 N. Y. 300, 303, 142 N. E 670, 671 (1923), as inferentially explained in People v. Pignataro, 263 N. Y. 229, 234-235, 188 N. E. 720, 722 (1934); also F. R. Patch Mfg. Co. v. Protection Lodge, 77 Vt. 294, 329, 60 Atl. 74, 84 (1905). Jones v. Thomas, [1934] 1 K. B. 323, under a statute requiring corroboration of complainant in a material particular, clearly suggests Evans' theory. Cf. Commonwealth v. Clark, 14 Gray 367, 373 (Mass. 1860) ; Boyle v. Columbian Fire Proofing Co., 182 Mass. 93, 103-104, 64 N. E. 726, 730 (1902); and Belding v. Belding, 358 Ill. 216, 220-221, 192 N. E. 917, 919 (1934), in all which language is used less from the point of view of limiting the effect of an implied admission than from that of showing a legitimate effect attributable to it. Anderson v. Irwin, 101 Ill. 411, 416 (1882), and Tanton v. Keller, 167 Ill. 129, 144, 47 N. E. 376, 380 (1897), are examples of cases asserting that one whose opponent deliberately destroys a writing need not make strict proof of contents. Their idea scems to be not merely that a slight showing will support a finding of relevance (see p. 236, stipra), but that the spoliation effectively emphasizes such showing. 
knowledge, and is the sole judge of its character and weight, and determines whether it is favorable or unfavorable to the party." Bs But with this we do not agree. About any witness there is always a question of credibility, and many uses of documents involve questions of authenticity, accuracy, and variable inferences. To get the whole "courtroom truth" on either witness or writing, the jury should know that the defendant was so apprehensive as to try to suppress the evidence. ${ }^{\text {s3 }}$

Putting behind us this common but specialized situation, we begin on the general question by repeating a suggestion already made. Since parties now have all sorts of compulsory process to help them get at evidence even from opponents, it may be wise policy to reverse the old practice of exaggerated inference from suppression and underrate such inferences instead. If, from a purely logical point of view, this be artificial, our practical student of public policy will perhaps applaud the device for encouraging or compelling acquisition and presentation of definite, solid proof. Such argument holds, however, only for suppression short of destruction or claim of legal privilege. It weakens or fails where an opponent burns a paper, kills a witness, or clings tight to a self-incriminating document composed by and belonging to him.

More broadly, if less reasonably, the Evans doctrine has delightful simplicity and definiteness. Nobody can blame a judge for loving a

58. Harrison v. Harrison, 124 Iowa, 525, 527, 100 N. W. 344, 345 (1904). Wilson v. Grace, 273 Mass. 146, 153, 173 N. E. 524, 527 (1930), seems to malie a remariable sugsestion. $W$ testified to a material fact and also testified that when he previously told plaintiff of this fact the latter urged him to report it falsely to an insurance company. Plaintiff had no occasion to know about the fact before W told it to him. Yet the opinion seems to consider it worth deliberating whether plaintiff's conduct "was an admission of the truth of $[W$ 's] statement . . . " How can an extrajudicial "admission" by an utteriy uninformed man add force to the positive testimony of an informed witness?

59. The case of testimony by a witness who alleges that his virtue has triumphed over a litigant's improper blandishments or worse is of course very common. The effect of the implied admission is not always carefully thought out. State v. Alesander, 184 150 . 266, 270-271, 275, 83 S. W. 753, 754, 755 (1904), evidence of persuasjon, money, and threats admissible as "tending to show the consciousness of guilt on the part of the defendant; so, too, the weight to be attached to it was a matter for the considerntion of the jury"; State v. Mathews, 202 Mo. 143, 146, 148-149, 100 S. W. 420, 421 (1907), threats and promises an "admission by conduct that the party's cause is an unrightcous one" and indicate "consciousness of guilt"; State v. Howe, 287 Mo. 1, 6, 7, 11-12, 223 S. W. $477,478,479$ (1921), "Evidence is always admissible for the purpose of showing that the accused has attempted to procure false evidence or destroy evidence against himself." In these quotations there is too little analysis of the content of the textimony sought to be headed off. Cruikshank v. Gordon, 48 Hun 308, 309-310, 1 N. Y. Supp. 443 (2d Dep't 1888), 118 N. Y. 178, 187, 23 N. E. 457,459 (1890), is blind in the uppor court but definite below: "A witness for the plaintiff testifies to one of the slanderous utterances, and ... that defendant offered him $\$ 1,000$ to go to Canada to avoid testifying on the trial. The real point of the evidence of this vitness was an intent [attempt?] to induce the witness by defendant to 'not remember' . . . . It was a virtual admission of the speaking of the slanderous words." 
rule of thumb which gives him a universally applicable stock tag to his jury charges. Several citations already offered show the yearning for brass-bound formulas in the present connection. ${ }^{60}$ To which it will be replied that simple fixity is not justice in a world of infinite variation. Let us try, then, to peg this same idea higher on the intellectual scale. From time immemorial Anglo-American courts have shown determination to hold jurors' eccentricities within limits. Consider, for instance, the handling of probable cause in malicious prosecution; the judicial interpretation of writings; the doctrine of judicial notice; and the whole theory of presumptions. In manipulating such implied admissions as we are discussing, there is really formidable intellectual diffculty, and conscientious jurors may be grateful indeed for a comprehensive rule of thumb instruction. If, as is obviously the case here, the rule of thumb sedulously avoids overstating the significance of implied admissions, it may have some effect in restraining reckless appraisal of evidence by jurors not utterly conscientious. Emphatically our implied admissions do hold out threats of undue prejudice and general inflammatory effect, ${ }^{61}$ particularly as the conduct giving rise to them moves deeper and deeper into the morally reprehensible. Judges themselves have not been immune to such prejudices, as witness Pomeroy v. Benton, where the facts never went to a jury at all and a majority of the Supreme Court ripped to pieces the more temperate findings of a referee. Hence it cannot possibly be imagined that an admonitory rule of thumb would control a really inflamed jury. With such "lay gents", to use the words of a famous old malicious prosecution case ${ }^{62}$ there is no thoroughgoing safeguard save where the circumstances justify either a refusal on the part of the trial judge to submit the issues at all or the setting aside of a verdict. The rule of thumb derived from the Evans doctrine would create such occasions more often than a rule giving implied admissions from obstructive conduct a general substantive value. For, under the former rule, the ordinary evidence sought to be supported by the admission is required to have per se an optimum value justifying submission of the issue on which it bears.

Lest the foregoing passages be misinterpreted, we hasten to state explicitly that they represent only our exposition of a possible line of thought. Whether that line has a value outweighing the disadvantages of rigidity is a question which cannot be answered at all without much further intelligent experimentation than the decisions thus far mani-

60. See the passage from Beccaria in note 37 , supra, and the Illinois and Louisiana citations in note 41 , supra.

61. This is well put in People v. Sharp, 107 N. Y. 427, 464-465, 14 N. E. 319, 342 (1887). Nor should one forget the case of the vanished niece and the unfortunate uncle, described by Coke in the Third Institute, cap. 104.

62. Pain v. Rochester, Cro. Eliz. 871 (1602). 
fest, and which very likely calls for different answers in varying categories of litigation. Our concluding section offers some suggestions upon the problems of this paper at large which have particular pertinence to the subject immediately under comment. ${ }^{03}$

\section{$\mathrm{V}$}

\section{Implied Admissions for Purposes of Impeachment Only}

As already stated, other obstructionistic acts than suppression of evidence may form bases of implied admissions. Some of the cases hitherto cited illustrate this. But more comprehensive comment is desirable. Suppose the reverse of suppression-an attempt to fabricate evidence. The hypothetical sale of goods plaintiff calls $W$ to testify that defendant bribed $W$ to assert falsely that $W$ was present when $A$ arrived with the goods, heard defendant tell $A$ that he had ordered no such goods, and saw $A$ take the goods away. If believed, this testimony is perfectly pat as to defendant's apprehensions on the issue of delivery, and might, in respect to that issue, be given just as much general substantive effect or limited confirming effect as evidence that defendant tried to bribe $A$ to refrain from testifying. But suppose W's testimony is only that defendant in general terms offered him a bribe to testify on the defendant's side. $^{64}$ There are more issues than one, and we now have no firm logical tie with all or any of them. This is only a floating implied admission. Punitive impulse might give it substantive effect as to every litigated issue; cautious logic might well deny it any effect save a general impeaching backlash at defendant's case, he having disclosed himself as a tricky fellow who may have done dirty work at other cross-roads in his proof. Similar contentions may be advanced as to evidence of an attempt to bribe a juror at a former trial of the same case. ${ }^{65}$ And so, perhaps,

63. Pp. 257-259, infra.

64. DeGroodt v. Skrbina, 111 Ohio St. 108, 114, 144 N. E. 601, 603, 38 A. I. R. 591, 594 (1924), offer of money for "standing on my side"; no statement of any precice topics on which witness might testify; opinion quotes Wigmore that evidence of admissions by a party comes in because "clearly inconsistent with the truth of his contention"; the annotation in A. L. R. is good. MIcHugh v. McHugh, $186 \mathrm{~Pa}$. 197, 40 Atl. 410 (1893), contains illustrations of attempts to fabricate testimony both generally and specifieally. In Nowack v. Metropolitan St. Ry. Co., 166 N. Y. 433, 435, 437, 60 N. E. 32, 33 (1901), objections prevented disclosure of the precise fabrication intended; the opinion uses terms of impeachment rather than substantive use or even limited confirmation. Gebhardt $v$. United Rys. Co., 220 S. W. 677, 680, 9 A. L. R. 1076, 1081 (1920), is precise as to the false testimony desired, vague as to the evidentiary value of the showing of attempted bribary. Rex v. Watt, 20 Cox Cr. Cas. 852 (1905), contains a somewhat careful exposition of the rationale of implied admissions, but is indeterminate as to their probative effect.

65. Hastings v. Stetson, 130 Miass. 76 (1881), "You go for me" or "You do what is right, and I will pay you for it." State v. Friend, 210 Iowa 980, 989, 230 N. W. 425, 429 (1930), does not decide whether such evidence is usable only for impeachment. 
when there is a showing that defendant threatened a witness or sought to get him to leave the state, it not appearing that there was definite knowledge or suspicion as to what testimony the witness would give. ${ }^{00}$

A fairly common basis offered for implied admissions is evidence that after plaintiff's claim arose or his action began, defendant conveyed away his property under suspicious circumstances. The argument is: $\mathrm{He}$ seeks to avoid attachment, execution, or both; therefore he believes himself liable; therefore he is liable. As practitioners in a Commonwealth allowing great freedom of mesne attachment, we regard this argument with deep skepticism. Entirely apart from views on the merits, it is customary for Massachusetts lawyers to prevent inconvenience to their clients by rigging devices to impede attachment. Avoidance of execution is a little harder to explain, but may well result from appreciation of juries' vagaries instead of doubt as to the justice of a party's cause or even the truth and cogency of his evidence. ${ }^{07}$ Closely related to such cases, and enjoying more enthusiastic acceptance, is evidence that an accused man ran away ${ }^{68}$ or tried to bribe an officer to let him go. ${ }^{69}$ It seems to us that all these kinds of evidence should be handled with cautious discrimination, and usually restricted to impeachment of the actors' cases. Granting general substantive effect to the evidence is dangerous, and limited confirmation is hard to work out and justify. It does not follow that merely because the defendant shows himself tricky or apprehensive, the plaintiff or prosecution must be lily white or have an impregnable case. But the addition of special circumstances may have an important effect. Thus, in our hypothetical sale of goods case, suppose $X$ had been near enough to hear the interview between defendant and the delivery agent $A$, but $X^{\prime} s$ proximity was not then known to defendant. Immediately after discovering that $X$ was within earshot, defendant gratuitously conveys all his property to his wife. The fact of the transfer bears most pertinently on the issue of delivery. ${ }^{70}$

66. Such may have been the case in Commonwealth v. Smith, 162 Mass. 50s, 509-510, 39 N. E. 111,112 (1895). In Maynard v. Bailey, 85 W. Va. 679, 682, 102 S. E. 480 , 481,9 A. L. R. $981,982-983$ (1920), the threatening letter possibly indicates lack of information as to what the addressee might say. (1930) 9 TEx L. REv, 100 discusses threats, etc., against witnesses. (1929) 62 A. L. R. 133, 136 collects cases on evidence of threats to keep witnesses away from criminal trials.

67. Some cases are collected in (1930) 65 A. L. R. 1304, 1307, and (1932) 80 id. at 1131, 1139. See also Banfield v. Whipple, 10 Allen 27, 31 (Mass. 1865), and Carroll v. Carroll, 262 Mass. 10, 159 N. E. 517 (1928), which last may well be construed as embodying an express admission.

68. Cases are collected in (1923) 25 A. L. R. 876, 886. The question of relevancy may easily become very difficult. Suppose, for instance, the runaway may have been guilty of murder, robbery, and bootlegging, and is on trial for the last only.

69. Cases are collected in (1934) 93 A. L. R. 805, 810.

70. Cf. State v. Rowe, 24 S. W. (2d) 1032, 1036 (1930), where the evidence was that 
From the foregoing paragraphs the reader will perceive that we regard mere general impeachment as the pis aller of the implied admission. Much matter denied more specific value may be admitted for this use. We might well let in evidence of careless destruction of documents, not to infer their contents but to suggest a slovenly and unbusinesslike general attitude by the destroyer, affecting the weight to be accorded his other evidence. And so, to prove general trickiness, evidence that defendant hastily burned unread papers might be used. But some matter is too tenuously connected with litigated issues to cling even here, despite its indication of obstructive tendencies. ${ }^{71}$

\section{VI}

\section{Supplemental Topics}

So far, we have avoided questions of agency and the like. What about affecting a party by evidence of other persons' obstructive conduct? Can there be vicarious implied admissions? Moore v. Atlantic Coust Line Rr. Co ${ }^{72}$ is interesting both on its facts and in its reasoning. Fire destroyed plaintiffs' building, and they sued the defendant railroad, claiming that the conflagration had been started by sparks from a locomotive. A man $O$, found to have been as well acquainted with the facts as at least one of the plaintiffs, became active in rounding up testimony. There was evidence justifying a finding that plaintiffs knew what $O$ was doing and accepted the benefit of the testimony he procured. Two witnesses, in the jury's absence, testified that $O$ and another man ofiered them $\$ 75.00$ each to testify to facts indicating that sparks from a locomotive caused the fire. Three more witnesses, one of whom was $O$ 's brother and the others of whom had been in contact with $O$ since the fire, testified to "substantially the same story" sought from the first two witnesses. The trial judge refused to let the evidence of these two witnesses

defendant caused witness to be attacked and badly injured immediately after the hiter's refusal to support an alibi. MIcInturff v. The Insurance Co. of N. America, $243 \mathrm{III} .92$, 93 N. E. 369 (1910), does not discuss an apparent opportunity to develop an implied admission where a litigant lilled a witness after the latter had testified against him. Banach v. Bohinski, 107 Conn. 156, 157-158, 139 Atl. 688 (1927), preents just the reversa; exclusion of evidence of a conveyance to defendant's wife sustained becuse "ncither the deed itself, nor the other circumstances disclosed by the record, afford legitimate inference that it was prompted by any consciousness of liability."

71. So, for instance, a party's falsehood in respect of a fact foreign to the immediate issues has precarious evidential standing; it is extremely like impeachment of a witnes by evidence of specific irrelevant lies. But see Miasterson v. Berlin Street Ry., 83 N. H. 190, 193-195, 139 Atl. 753, 756-757 (1927). Incidentally we note a suggetion that where an implied admission is confined strictly to an impeaching office, it exactly pamallels a prior contradictory statement for witness impeachment, and esapes all hearsay taint. Doe v. Lucy, 83 N. H. 160, 162, 139 Atl. 750, 751 (1927).

72. 137 S. C. 319,323 et seq., 135 S. E. 473,474 et seq. (1926). 
as to attempted bribery be put before the jury. On defendant's appeal from an adverse judgment, this was held to have been error. The opinion seems to argue that defendant had made a sufficient circumstantial case of authorization or ratification by plaintiffs of $O$ 's acts, and aside from this "an innocent party is no more entitled to reap the benefit in a Court of justice of the corrupt practices of others than a party who has personally participated in the corrupt acts .... Courts are concerned with the purity of the stream which has been introduced into the channels of justice and not with fixing responsibility for its pollution."78

This case may be interpreted conservatively or liberally. The conservative reading suggests a composite rule involving three principles. (1) The remarks quoted at the end of the last paragraph certainly are sound, and would permit impeachment of plaintiffs' case in all aspects over which $O$ is found to have exerted influence. On the showing above, the testimony of the three witnesses could be thus impeached. This is permissible quite aside from any authorization by plaintiffs, but of course the fact and scope of $O$ 's influence must be established by competent evidence or reasonable inferences. (2) Evidence of $O$ 's conduct does not justify erection of an implied admission with general substantive force or even limited confirming effect except so far as plaintiffs learned, comprehended, and approved what $O$ had done. Why does our statement exclude $O$ 's conduct if originally authorized by plaintiffs? For the simple reason that under such conditions the admissions are found in the authorization, not in the subsequent conduct, and may therefore be attributed directly to the principals without any talk or thought of agency. So, under this conservative analysis, all true implied admissions by agent reduce themselves to adoptive admissions, and do not represent any general application of the "talking agent" doctrine. The argument for such a conclusion is that implied admissions depend upon the state of the litigant's mind in fact and not upon any artificial attributing of responsibility for the talk or acts of another. (3) Following the same line, any attempt to make $O$ 's belief that plaintiffs have a weak case serve per se as substantive evidence of the fact believed or even impeach any part of plaintiffs' evidence, except so far as $O$ enunciates that belief under standard testimonial sanctions, runs smack against the barrier of hearsay. ${ }^{74}$

73. 137 S. C. $319,333,135$ S. E. 473,477 (1926).

74. 1 WIGMORE ON EvIDENCE (2d ed. 1923) $\$ \S 265$ et seq. In Winchell va Edwards, 57 IIl. 41,48 (1870), where ties of relationship and perhaps of technical privity bound appellees to the persons suspected of misconduct, the court said that "the fabrication of evidence .. r raises a strong presumption against those who appear to be real parties to the suit, which must affect the case of the appellees, however innocent they may be." Dorris v. Commonwealth, 227 Ky. 809, 14 S. W. (2d) 136, 62 A. L. R. 133 (1929), whcro the prosecuting witness testified, holds the admission of evidence as to threats and bribery 
But now suppose that our principal, instead of being human, is a corporation. Principle (1) holds easily enough. The practical phrasing of principle (2) requires careful consideration. Where shall we find "the state of the corporate mind"? Surely not alone in duly assembled stockholders' meetings. Indeed, that might be about the last place to look for knowledge of business details. Fully appreciating this difficulty, a leading New York case, considering asserted efforts by a street railway claim agent to bribe a witness, thus summarizes its doctrine:
"He was not working for himself, but for the defendant [corporation], and, as he represented it with reference to the subject of witnesses, his conduct not only tended to show that its case was weak, for witnesses are not bribed unless it is thought necessary, but to cast a doubt upon the testimony of the other witnesses who were looked up by him and sworn by the defendant. It indicated as a result of his investigation for the defendant that honest witnesses could not be procured who would swear to a defense."

The corporate concept obviously does necessitate some such attribution of responsibility for the impliedly manifested beliefs of agents, but the attributing might be stopped at a point higher up the scale-specifically, with the executive in general control of the claim agents. Thus where a Massachusetts criminal defendant sought to prove efiorts by an interpreter and a police officer to buy false testimony from persons who did not actually take the stand, rejection of defendant's offer was sustained. But the court would admittedly have been troubled had the prosecuting officer authorized the bribery. ${ }^{76}$ Even this latter and more limited

respecting this witness by defendant's mother and sister erroneous, there being "not a line of evidence that appellant knew anything about any threats, if they were made, or that he knew anything about the giving of money, if any was given." Rer v. Watt, 20 Cox Cr. Cas. 852 (1905), where there was evidence of false testimony at an earlicr stage of the case, says that defendant is not presumed responsible for such perjury; there must be, and in the actual case was, connecting evidence. And see People v. Sharp, 107 N. $Y$. 427, 463-466, 14 N. E. 319, 342-343 (1887), where important witnesses had run away to Canada. Gregory v. Sorenson, 214 Iowa, 1374, 1379, 242 N. W. 91, 94 (1932), contains a passage commending instructions that testimony of $X$ 's efforts to influence a witnes "should not be considered unless [X] was the agent of the appellant or unless appellant ratified her actions and statements after they were committed or made." Obviously, "was the agent" means "was instructed to do exactly or substantially what she did". Why did not the judge make the finding of agency as a preliminary matter? Aldrich v. Aldrich, 215 Mass. 164, 168-169, 102 N. E. 487, 489 (1913), seems to lose its way in metaphysios. This was a will contest involving alleged undue influence. The beneficiary asserted to have exercised such influence, being named as executris, propounded the will. The opinion appears to say that as beneficiary she "is not an adverse party, and . . . may be called as a witness either by the executor [sic] or contestant, and the failure of the proponent ... to give evidence in support of the will she was required to offer . . . did not convert her silence into an inference of fact to be drawn by the jury, that if she had testified her testimony would have been prejudicial to its validity."

75. Nowack v. Metropolitan St. Ry. Co., 166 N. Y. 433, 439, 60 N. E. 32, 34 (1901).

76. Commonwealth v. Min Sing, 202 Mass. 121, 123, 125 et seq, 88 N. E. 918, 920 
formula for corporate principals evidently requires some modification of principle (3) as to the non-effect of an agent's belief as such. Massachusetts and New York alike are saying that to some extent the mind and the beliefs of an agent may become acceptable in court as the mind and beliefs of the corporation.

Having thus far widened the possibilities where an incorporated litigant is concerned, we find a further attractive opening for liberalization where the principal, human or corporate, has said: "Agent, I know nothing of this claim against me. Go out, ascertain the facts, and take every needful measure to make my victory as sure as may be." This blanket authorization, if it really expresses the state of the principal's mind, is an express admission of ignorance rather than an implied admission of liability. But if an agent so instructed went forth and, without ever reporting to his chief, subsidized witnesses to commit perjury, it seems highly unlikely that evidence of the misconduct would be given less effect than if the principal had fully ratified the agent's acts or done like acts directly himself. ${ }^{77}$

Our second and final supplementary topic has some apparent connection with the question of implied admissions by agent, but fundamentally leads into very different considerations. Somewhat over twenty years ago, a freight brakeman swinging off the side of a box-car was struck and fatally injured by the locomotive of a speeding express train. His widow sued the railroad for wrongful death, and in her action had the burden of proving that at least one member of the express engine crew saw the freight brakeman in a position of peril soon enough to give him effective warning. Both engineer and fireman testified that they did not see the unfortunate victim "earlier than an instant before he was struck." Other direct evidence on the issue was lacking. The jury returned a verdict for the widow, perhaps disbelieving the foregoing testimony. So there came before the upper court the question whether jurors might as it were put a backspin on the trainmen's disavowals. The court disposes of this in a sentence: "Mere disbelief of denials of facts which must be proved is not the equivalent of affirmative evidence in support of those facts." Judgment was entered for the defendant. ${ }^{78}$

et seq. (1909), a careful and comprehensive opinion. Cf. Commonwealth v. Enwright, 259 Mass. 152, 157, 156 N. E. 65,67 (1927): "It is assumed, however, that if the district attorney should unfairly suppress evidence he would thereby subject the case of the Commonwealth to the same adverse inferences as would result from similar conduct by any other party to a cause." Freeman v. Kansas City Public Service Co., 30 S. W. (2d) 176, 181-182 (Mo. App. 1930), admits against a street railway evidence that the railway's lawyer advised a motorman to claim privilege against self-incrimination at an inquest, and that the motorman then made the claim, speaking through this lawyer.

77. Consult on this topic 2 Restatearent, Agency (1933) $\$ \$ 286$ et circa.

78. Cruzan v. New York Central \& Rr. Co., 227 Mass. 594, 597, 116 N. E. 879, 880 (1917). The printed record shows (pp. 5, 6-7, 11, and 12) that the fireman testified he saw 
This is representative of many cases. ${ }^{79}$

The principle stated in the foregoing quotation is obviously correct so far as a testimonial assertion (positive or negative) simply fails to move the mind of the trier of fact-leaves him a neutral unbeliever rather than an active disbeliever. Also, the principle is unassailable so far as the trier of fact accepts the reverse of a testimonial assertion solely because of his own stupidity, obstinacy, or prejudice. No sound thinker could applaud a conclusion thus unreasonably reached. But so far as the trier of fact accepts the reverse of a testimonial assertion because he reasons intelligently from some factor beyond the assertive words in and of themselves, the principle is debatable. Nobody would think of denying that, if defendant testified: "I did not strike the plaintifi", and $X$ testified: "Defendant struck plaintiff", there might be a proper finding that defendant struck plaintiff. Equally, or almost equally, nobody would deny that, if defendant so testified and evidence was given that he had previously said: "I struck the plaintiff", a like finding might be proper. It may be suggested that this, falls beyond the stated principle, as not being an instance of "mere disbelief"; the jury chooses or elects between defendant's testimony and X's testimony in the first case, between defendant's testimony and his own admission in the second case. But surely this general kind of situation was in the court's mind when it framed the statement of principle quoted above, for prior self-contradiction by the fireman or engineer might have been shown.

At this point, of course, the hearsay rule forces a differentiation. Extra-judicial statements by a litigant may be used substantively against him as admissions. Extra-judicial self-contradiction by a third party witness is, according to the standard rulings, inadmissible hearsay if offered for substantive use and not confined to impeachment. Suppose, though, that the denials of the fireman and the engineer were disbelieved because of suspicious circumstances observed in the manner and answers of the witnesses while on the stand. This puts hearsay out of the picture, and we frankly doubt whether in such a situation common sense should permit disparate treatment of litigant's and third party's disbelieved testimony. However, a sharp technician might contend that so far as a court respects the conventional stupid rule forbidding a litigant to impeach his own third party witness, the same court ought to furnish a

the brakeman "hanging off the side of the freight car just before the engine strucl him"; the engineer, that he knew nothing of the accident until the fireman said it had happened. Plaintiff's brief seeks to argue from the condition of the track, etc., that the fireman saw the victim sooner.

79. One of the more recent decisions is Clairmont v. Cilley, 85 N. H. 1, 7, 153 Atl. 465,468 (1931): "Falsity of testimony is no proof of what is true and disbelief does not supply the need of proof .... Otherwise any fact might be proved by diserediting testimony to the contrary. While the falsehood of testimony may add to the weight to 
crude counterbalance by arbitrarily denying substantive force to his opponent's impeachment of that witness through implications from the witness's testimony or behavior on the stand. Even this super-ingenious contention becomes inapplicable, if, during legitimate cross-examination, defendant elicits assertions favoring him from plaintiff's witness, and something then or thereafter occurring in the interrogation of the witness causes the jury to disbelieve these assertions. Should plaintiff argue for granting substantive effect to the disbelief, defendant could not truthfully reply that he, the cross-examiner, had been blocked off from impeaching the witness.

But we should waste time by arguing elaborately about possible distinctions between litigants and third parties as witnesses, for judges show little inclination to turn actively against a party even his own testimony because found untruthful or mistaken. ${ }^{80}$ There is distinct reluctance to give implied self-contradiction the same effect as contradictory testimony by others or express contradictory admissions by the litigant-witness himself. Still, some peculiar opinions are found, as for instance in a Massachusetts decision where plaintiff had been in collision with a taxicab, alleged to have been defendant's. Defendant testified that he operated ten taxicabs, including one bearing the registration number which plaintiff took down at the accident; but that $W$, whose name plaintiff obtained as that of the driver of the taxicab in the collision, although employed by defendant, was not working for defendant on the night of the accident; also that defendant knew of no collision involving the particular taxicab on the night in question. $W$ testified that he was not driving at the material time and knew nothing of the accident. Sustaining a finding for plaintiff, the court says:

"False testimony of a party may have probative force in civil cases. If the judge who saw the witnesses and heard them speak believed that the defendant wilfully swore falsely and was in collusion with the driver in misstatement of the facts he could have considered such conduct on the part of the defendant as in the nature of an admission from which with

be given evidence to the contrary, the testimony by itself does not go far enough to establish the fact it denies." Consider in this connection the multitudinous assertions that prior contradictory statements by third party witnesses must not be given affirmative probative force. E.g. Southern Railway Co. v. Gray, 241 U. S. 333, 337 (1916), cited in tho Cruzan case, supra note 78.

80. Moulton v. Moulton, 178 Minn. 568, 569, 227 N. W. 896, 897 (1929), where plaintiff had to prove the fictitious character of an alleged indebtedness between the two defendants, and her only evidence came from defendants, who steadfastly maintained that there was a genuine indebtedness. Said the opinion: "The court could not find a fact necessary to be proved, namely that there was no debt, as to which there was no affirmative testimony, by a claim that the negative testimony was unworthy of belief. This is the holding of the cases throughout." Cf. (1911) 21 Ann. Cas. 1121, 1123. Atlas v. Silsbury-Gamble Motors Co., 278 Mass. 279, 283, 180 N. E. 127, 128 (1932), faintly differentiates litigant from third party. 
other evidence liability might be inferred. . . . In weighing the other testimony in the case with the defendant's testimony and conduct the judge could have inferred that the defendant's driver was operating the taxicab under such conditions as made the defendant responsible for his acts. ... The conduct of the defendant could be found to have probative force because of its tendency to prove a consciousness of liability and an endeavor to escape from it. ... In the circumstances disclosed by this record, mere disbelief in testimony is not given effect as positive proof of the fact denied." 81

These remarks will bear some unravelling. Perhaps there is a suggestion that the tribunal might reasonably have inferred a collusive understanding between defendant and his driver to "cover up" on the facts touched by their testimony. Any such prearrangement gives some basis for an implied admission, the evasive testimony later proffered being used only to evidence the nefarious scheme. ${ }^{82}$ Going beyond this interpretation, we encounter a definite logical difficulty. Suppose the defendant says: "My taxicab was not in the collision, nor was its driver working for me at the moment." Discrediting the first assertion will primarily wipe it off the evidential slate, and may secondarily sideswipe defendant's credibility in his second assertion. But now suppose the whole statement is: "My taxicab was involved in the collision, but the driver was on a frolic of his own." We cannot, runs the common argument, believe the contrary of the "frolic" assertion until competent evidence has convinced us that the driver was acting for his master; hence we can never reach the latter conclusion in a case barren of other evidence on the issue; furthermore, once having reached that conclusion on such other evidence, we should be guilty of a futile superfluity in talking about the probative effect of mere disbelief. ${ }^{83}$ This second interpretation explains the result, although not the language, of the case under examination, for there seems to have been substantial other evidence on both the contested issues. It also explains some other cases superficially at odds with the general denial of probative backspin. ${ }^{84}$ Further, it is quite unassailable when the litigant's disbelievable statement was extra-judicial, as where the prosecution seeks to give evidence that a policeman said to defendant: "You are the guilty man", when the only reply made was: "I am not," and evidence is lacking of concurrent or independent guilty behavior. ${ }^{85}$

81. D'Arcangelo v. Tartar, 265 Miass. $350,352,164$ N. E. 87, S8 (1928).

82. Atlas v. Silsbury-Gamble Motors Co., 278 Mass. 279, 283, 180 N. E. 127, 128 (1932), bears out the interpretation suggested above.

83. See Maguire, Adoptive Admissions in Mlassachusetts (1929) 14 MLAss. L. Q. (no. 6) 62,76 n. 54.

84. E.g. Barrie v. St. Louis Transit Co., 102 MIo. App. 87, 92, 76 S. W. 706, 707-703 (1903); where the physical facts contradicted plaintiff's denial of looking for the car and not seeing it; he seems to have been in a dilemma-if he looked, he must have ssen, and if he did not look, he was culpably' negligent.

85. Commonwealth v. Trefethan, 157 MIass. 180, 199, 31 N. E. 961,968 (1892). 
Nothing more damaging than neutral unbelief is justified on such a showing. But if a litigant takes the stand and testifies that a certain thing occurred, why may not his hang-dog demeanor properly permit the jury utterly to disbelieve him, even though there is no other evidence on the issue?

To the question just asked, a recent Utah opinion forcibly replies by asserting ignorance of any authority "for the broad proposition that a trial court is justified in basing affirmative findings on negative evidence merely because of the appearances of the witnesses. While the demeanor of the witness in testifying is very important and should be given consideration by the trier of fact, still there must be something more than the batting of an eye, the coloring of the cheek, or the twiddling of the thumbs as a basis for finding facts." ${ }^{386}$ Well and good, but this very opinion cites and quotes from a Massachusetts case ${ }^{87}$ standing for the proposition that a jury may "find, in the very teeth of a denial by a witness, an opposite conclusion based upon inferences from other parts of the evidence." 188 This proposition we have already suggested as beyond criticism. Certainly we do not suspect the Utah judges of denying it. Neither, presumably, would they deny that "other parts of the evidence" might be supplied by the particular witness himself. Suppose the plaintiff in a personal injury case testified positively that he was stone deaf and therefore had not heard a warning signal. However, when counsel standing behind the witness's back denounced him as a perjurer, the witness turned purple with rage and assaulted the lawyer. A finding that the witness could hear would be entirely proper. The Utah opinion is simply warning us (1) that such effective self-refutation is not to be assumed and (2) that its occurrence must therefore appear in the appellate record if the case is carried up. Where the facts are tried to a judge, master, auditor, or referee, the finding or report can easily state the refuting circumstances. Where the trial is by jury, counsel must be sufficiently alert and ingenious to get some statement of the circumstances into the stenographic notes. This last problem is nothing new. Every experienced advocate realizes the need of shaping his evidence so that its printed reproduction will strike the eye of the upper court somewhere nearly as effectively as the original presentation struck the jurors' senses.

Still a third interpretation of the Massachusetts opinion quoted above is that it permits probative backspin to the extent of limited confirmation. This fits both result and language. It is not without support from other jurisdictions. ${ }^{80}$

86. Chapman v. Troy Laundry, 47 P. (2d) 1054, 1062 (Utah, 1935).

87. Elliott v. Baker, 194 Mass. 518, 520-521, 80 N. E. 450, 451 (1907).

88. McDermott v. Sallaway, 198 Mass. $517,519-520,85$ N. E. 422,423 (1908).

89. See the language quoted from Clairmont v. Cilley, note 79 supra; also the result 
The best which can be said of the foregoing paragraphs is that they raise honest uncertainties. Suppose we try a second way of explaining such judicial hesitancy as the Utah court reveals. When a man says: "The train did not whistle until an instant before it hit him", he may be right or wrong. If wrong, his error may be (1) the result of unconsciously inverted or deliberately misstated recollection, or (2) the result of positively stating as a present recollection a version of an incident he has forgotten, or (3) the result of positively stating as a present recollection a version of an incident he never observed. But in (2) or (3) he may by chance hit the exact truth, and so it is illogical to infer the reverse of what the man asserts simply from finding that he never saw, or does not now recollect, the incident. This finding makes him a neutral testimonial factor. Such ambiguity of inference might explain the general denial of probative backspin. The obvious reply is that cross-examination and other methods of correction and impeachment should be relied upon to show the jury not only whether the testimony is defective but also the source and nature of the defect. Here again the arguments come close to a stand-off, and we are left uncertain.

A third explanation for the judicial hesitancy already noted is satisfactory so far as it goes, but inadequate. If disbelief per se operates as proof, it follows that the jury may always find on any issue unfavorably to the party who adduces testimonial evidence superficially favorable to himself, despite lack of other evidence respecting that issue. ${ }^{20}$ This introduces a highly anomalous possibility, freeing the jurors from judicial control to a disquieting extent. The explanation, however, is only a reiteration of what we have already said about the probative worthlessness of disbelief proceeding from stupidity, obstinacy, or prejudice. It fails where disbelief is reasonably induced by factors perceptible to the trial and appellate courts as well as to the jury.

\section{VII \\ Conclusion}

Employment of implied admissions for impeachment, proper logical foundations being assumed and the reasonable requirements of relevancy and materiality being otherwise respected, seems to encounter no judicial doubt and to raise no practical or theoretical difficulty. Employment of

and reasoning in State v. Poplowski, 104 Conn. 493, 133 Atl. 671 (1926), where the issue was whether defendant's horses had been permitted to be at large on a public highway without a keeper; general circumstantial evidence indicated the affirmative of this issue, and: "The defendant does not explain the presence of the horses on the highway. On the contrary, he tells a false story designed to show that his horses were not in fact on the highway ...."

90. (1929) 42 HARV. L. REv. 831, 832. 
such admissions, erected on the basis of conduct intended to obstruct the judicial process, for general substantive or affirmative purposes is theoretically justifiable, provided there be scrupulous compliance with the demands of logic. Considerable judicial hesitation about this latter employment, however, has been manifested. Considerable practical objection may also arise, partly because courts sometimes adulterate their logic with punitive enthusiasm, and partly too because, even where logic holds good, risks of undue prejudice threaten. Some courts, very likely with these latter risks particularly in mind, have to a perceptible extent refused this variety of implied admissions general substantive value, but have granted limited value in confirmation of other evidence. The available material is not yet adequate to determine the merits of this restriction.

Since experimentation must continue, we hope that it will become more conscious and less instinctive, and that consciousness will include a wider appreciation of possible controlling devices, especially the control of comment by counsel. Sometimes implied admissions arise automatically and without any offer of special evidence. Here our stock example is the failure of a criminal defendant to testify when the prosecution has raised issues of fact on which he has personal knowledge. This kind of thing bids fair to become increasingly important in view of the modern tendency to strip away the customary legislative "no comment or inference" provisions. The needed protection is against unjust argumentative exploitation of the accused's silence. One form of protection is to forbid comment, although not forbidding inference. Such was the Connecticut rule prior to 1879. ${ }^{.1}$ The English rule ${ }^{02}$ and the present Connecticut rule forbidding comment by the prosecutor but permitting comment by the court seem potentially wiser. Fair explanation from an impartial and experienced source ought to produce better results than the unguided speculations of laymen.

When there must be special evidence of obstructive conduct to lay the foundation for an implied admission, the best safeguard against bad logic or undue prejudice is found in careful scrutiny of the evidence before it is put to the jury. The principal logical risk arises from what we have called ambiguity of inference. It should be practicable for the courts on this point to enunciate definite tests, either generally or with respect to particularly difficult categories of cases. One obvious test would be that evidence of obstructive conduct shall not be admitted unless it appears to the judge sufficiently complete-to have sufficient background or setting-to enable reasonably intelligent jurors to make an effective appraisal, that is, to decide not by mere guess but by sober

91. State v. Heno, 119 Conn. 29, 174 Atl. 181, 94 A. L. R. 696 (1934).

92. Reg. v. Rhodes, [1899] 1 Q. B. 77, 83. 
consideration of all the circumstances if the hostile inference desired by the offering party may wisely and justly be drawn. ${ }^{03}$ Another test giving the judge a greater degree of control would call upon him to exclude the evidence unless he is able to make a preliminary finding that the hostile inference desired is the most reasonable conclusion to be drawn from the evidentiary showing. Such finding should not, of course, be binding upon the jury. ${ }^{94}$ Risks of undue prejudice must perhaps be dealt with more flexibly, but it is easily conceivable that here, too, certain defined practices requiring unusually positive proof would be desirable..$^{95}$ Beyond these general suggestions the authorities do not lead us. Continued obscurity in our field of study betokens multifarious dificulties which cannot be appreciated, let alone cleared away, unless practitioners and judges give them patient and open-minded consideration.

93. State v. Weber, 272 MIo. 475,199 S. W. 147 (1917), refuses to permit of trial the drawing of an inference from a claim of privilege at the preliminary liesring. It would have been hard for the trial jury to appraise intelligently such an incident vhen they did not see it. But the opinion does not suggest this esplanation of the result, and cites as analogous, a case in which the claims of privilege were made at the trial itcelf.

94. Normally, as is commonly recognized, if the admission of evidence is challenged only upon the issue of relevancy, the judge will let it in if a sufficient showing of relevanoe be made to sustain a favorable finding by reasonable men. See generally Mraguire and Epstein, Prelininary Questions of Fact in Deternining the Admissibility of Eviderce (1927) 40 HaRv. $L_{i}$ REv. 392, which is effectively criticised by Mlorgan, Furetions of Judge and Jury in the Determination of Preliminary Questions of Fact (1929) 43 id. at 165 . But considerations of practical policy permit stricter tests in appropriate cases. University of Illinois v. Spalding, 71 N. H. 163, 51 Atl. 731, 62 L. R. A. 817 (1901) (authentieation of handwriting standards).

95. Cf. State v. Hyde, 234 IIo. 200, 136 S. W. 316, Ann. Cas. 1912D, 191 (1910), evidence of other crimes to prove intent, etc. 